\title{
RELATIONSHIP BETWEEN CHEATGRASS COVERAGE AND THE RELATIVE ABUNDANCE OF SNAKES ON ANTELOPE ISLAND, UTAH
}

\author{
Lucas K. Hall ${ }^{1,2}$, John F. Mull ${ }^{1}$, and John F. Cavitt ${ }^{1}$
}

\begin{abstract}
Cheatgrass (Bromus tectorum) is an invasive annual known to negatively impact many shrub-dependent organisms; however, relatively little research has examined how it affects snake communities. Bromus tectorum is abundant at Antelope Island State Park, Davis County, Utah, and could be a possible threat to snake populations. Study sites representing different $B$. tectorum coverage percentages were established to measure relative abundance of snakes. Snakes were captured from June to September 2005 primarily by using funnel traps attached to drift-fence arrays. Linear regression revealed a negative relationship between B. tectorum coverage $(\%)$ and the relative abundance of the Great Basin gopher snake (Pituophis catenifer deserticola) and the western racer (Coluber mormon). These results (1) suggest that $B$. tectorum invasions result in reduced snake abundance in shrubsteppe habitat on Antelope Island and (2) add to our understanding of the relationships between B. tectorum and native fauna.
\end{abstract}

Key words: cheatgrass, Bromus tectorum, shrubsteppe, invasive annual, Great Basin gopher snake, Pituophis catenifer deserticola, western racer, Coluber mormon, relative abundance.

Cheatgrass (Bromus tectorum L.), an invasive annual from Eurasia, was detected in the western United States as early as the 1890s (Mack 1981, Novak and Mack 2001). It has since come to dominate more than $200,000 \mathrm{~km}^{2}$ of the shrubsteppe landscape in the Intermountain West (Mack 1989). Characteristics of B. tectorum that allow it to outcompete native perennials include abundant seed production and rapid germination (Stewart and Hull 1949, Aguirre and Johnson 1991, Humphrey and Schupp 2004, Chambers et al. 2007). Bromus tectorum alters plant community structure and microclimate by forming monocultures, thereby decreasing plant diversity (Hulbert 1955, D'Antonio and Vitousek 1992, Brooks 2000). It also reduces nitrogen availability (Evans et al. 2001) and increases fire frequency (Stewart and Hull 1949, Young and Evans 1978). Following a wildfire, B. tectorum is able to obtain (1) the nutrients that shrubs were using (preburn) and (2) the additional nutrients from post-burn vegetation. In that way, B. tectorum reduces nutrient availability and therefore limits vital resources for shrub regeneration (Young and Evans 1978, Chambers et al. 2007). Within a few years after a wildfire, $B$. tectorum becomes ubiquitous, causing shrub species to recede (Young and Evans 1978).
Bromus tectorum has been implicated in habitat loss and the subsequent decline of several shrub-dependent organisms (Knapp 1996, Pimentel et al. 2000) including small mammals (Gitzen et al. 2001), birds (Wiens and Rotenberry 1985), and lizards (Newbold 2005). However, little is known about how B. tectorum affects snake communities. Western Racers (Coluber constrictor) have been found in $B$. tectorum (Hirth et al. 1969), and although the occurrence of gopher snakes (Pituophis catenifer) in B. tectorum has not been well explored, other researchers have documented the presence of B. tectorum in their study areas while studying $P$. catenifer (Parker and Brown 1980, Diller and Wallace 1996). The generalized habitat preference of both snakes has been noted, but it should be understood that shrubs play an integral role in their ecology (e.g., thermoregulation, refuge; Fitch 1963, Parker and Brown 1980). On Antelope Island in northern Utah, B. tectorum is widespread in the shrubsteppe understory, and there may be potentially negative implications for snakes inhabiting B. tectorum-dominated areas (Mortensen 2004). The objective of this study was to examine the relationship between B. tectorum coverage and snake abundance. 


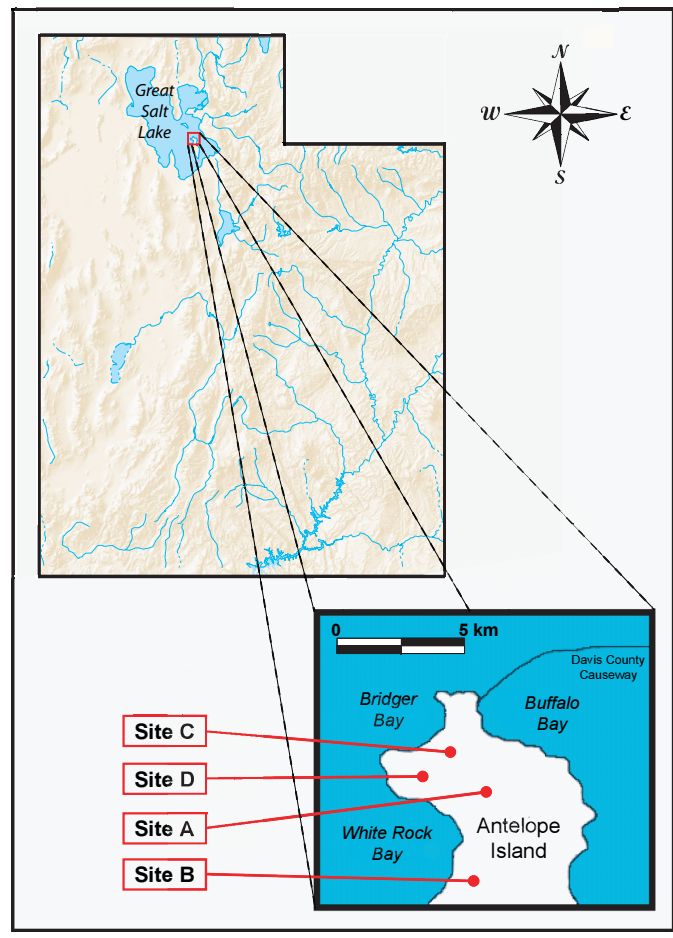

Fig. 1. Map of Utah with enlarged area showing study sites on Antelope Island, Utah.

\section{Methods}

This study was performed at Antelope Island State Park $\left(41^{\circ} 03^{\prime} \mathrm{N}, 112^{\circ} 14^{\prime} \mathrm{W}\right.$; elevation $1310 \mathrm{~m}$ ) in Davis County, Utah. Antelope Island is the largest island $\left(113 \mathrm{~km}^{2}\right)$ in the Great Salt Lake (Fig. 1) but is not a true island due to its causeway and a naturally occurring land bridge that becomes apparent during dry years. Bromus tectorum is one of the most abundant plants on the island. Other common vegetation includes bluegrass (Poa spp.), buckwheat (Eriogonum spp.), wheatgrass (Agropyron spp.), rabbitbrush (Chrysothamnus spp.), and sagebrush (Artemisia spp.) (Marshall 1940, Mortensen 2004).

Four study sites (3 ha each) were selected and surveyed from June to September 2005. Sites encompassed 3 ha because of the relatively small home ranges ( $\leq 3 \mathrm{ha}$ ) of western racers (Coluber mormon) and Great Basin gopher snakes (Pituophis catenifer deserticola) (Brown and Parker 1976, Parker and Brown 1980). Sites were located $\geq 0.7 \mathrm{~km}$ from each other and were similar in elevation $(\leq 40 \mathrm{~m}$ difference). Two sites were near White Rock Bay and 2 sites were near Bridger Bay (Fig. 1). Study sites were chosen to represent a range of B. tectorum coverages and similar vegetation. However, sites differed in plant species diversity. As B. tectorum coverage increased, plant diversity decreased, leaving fewer perennial grasses and shrubs. Sites were alike in that they encompassed field-like expanses and did not exhibit distinctive geographical features (e.g., hillsides, rocky outcrops, etc.).

Bromus tectorum cover was determined by estimation to the nearest 5\% (Daubenmire $1959)$ within a $1 \times 1-m$ wooden frame placed on the ground at $10-\mathrm{m}$ intervals along twenty $100-\mathrm{m}$ transects $(n=200$ samples per site). Transects were walked from the center of each plot and radiated out to the site boundaries, covering nearly the entire site. During the $B$. tectorum coverage survey, $0.67 \%$ of each site and $5.71 \%$ of the area covered by each trap array were directly sampled. Sites were statistically compared to determine if differences in B. tectorum coverage (\%) were significant using a one-way ANOVA followed by LSD post hoc tests.

In the center of each site, a hardwarecloth drift-fence trap array $\left(0.635 \mathrm{~cm}^{2}\right.$ mesh, $40 \mathrm{~cm}$ high $\times 30 \mathrm{~m}$ long) was established in an X-pattern. To eliminate soil irregularities and gaps between fence pieces, lower edges of fences were buried at least $5 \mathrm{~cm}$ deep. Attached to each fence were 10 double-ended hardware-cloth funnel traps $\left(0.635 \mathrm{~cm}^{2}\right.$ mesh, $38 \mathrm{~cm}$ high $\times 1 \mathrm{~m}$ long) placed $5 \mathrm{~m}$ apart (Cavitt 2000; Fig. 2). Traps were covered with white corrugated plastic to reduce heat stress to captured animals. We used funnel traps as the primary method of trapping snakes for data collection (Fitch 1987). In our analyses, we also included data from hand-captured snakes collected incidentally within the site by researchers traveling from the site boundaries towards the trap array $(175 \mathrm{~m}$ travel distance for each site), since there was no specific effort or additional time involved in the acquisition of these captures.

Captured snakes were identified (Collins and Taggart 2002) and sexed by hemipenal probing (Schaefer 1934) or hemipenal eversion for neonates (Rosen 1991). We measured snoutvent lengths (SVL) by contouring a metric vinyl tape along the side of the individual's body from snout to vent. We individually 


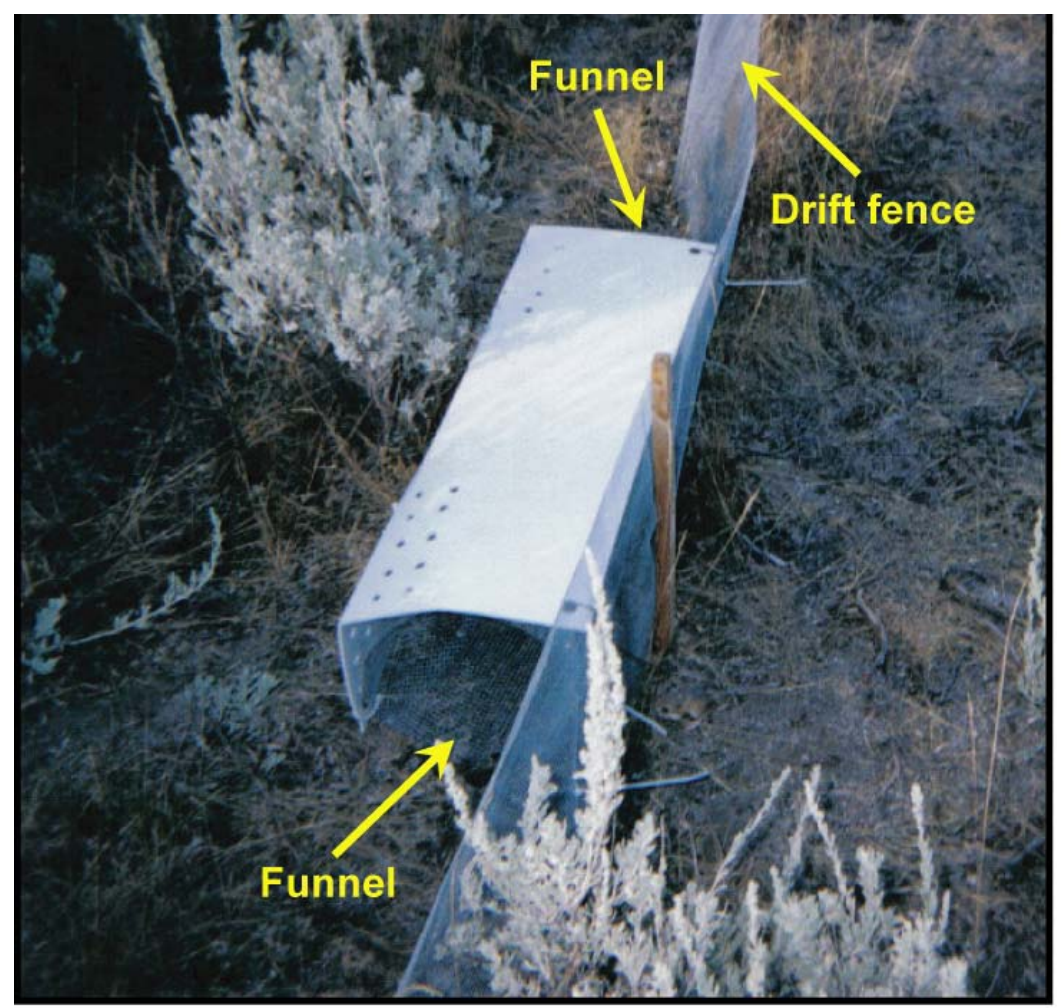

Fig. 2. Double-ended funnel trap with white corrugated plastic cover attached to drift fence.

marked snakes by clipping unique combinations of their ventral scales (Spellerberg 1977). Once marked, snakes were released at the point of capture.

Funnel traps at all sites were first opened in early June. Because air temperatures exceeded $38{ }^{\circ} \mathrm{C}$ in mid-July to early August, traps were closed to prevent heat stress and snake mortality. This was accomplished using round white corrugated plastic lids $(7.62 \mathrm{~cm}$ diameter) fitted inside the apex of the funnels. Trapping was discontinued in late September after an early frost.

For each species, we calculated site-specific relative abundance (total number of snakes captured per 10 days). Linear regression was used to determine if a relationship existed between snake relative abundance and B. tectorum coverage $(\%)$. Snout-vent length measurements were averaged to determine the species mean for each site. We performed a second linear regression to determine if $B$. tectorum cover was related to snake SVL. We used chi-square analyses to verify if sex ratios (males:females) differed significantly from parity. All statistical tests for regression and nonparametric analyses were conducted using Statistical Package for the Social Sciences (SPSS) software (version 13.0). Significance level was $\alpha=0.05$ for all statistical tests.

\section{Results}

Each of the 4 study sites represented different B. tectorum coverage (Fig. 3). The one-way ANOVA and LSD post hoc tests revealed that all sites were significantly different from each other, with the exception of sites A and B $\left(F_{3,796}=141.92, P<0.001\right.$; Fig. 3). Twentyfour C. mormon and 4 P. c. deserticola were trapped during 221 trap-array days. Four additional C. mormon and 3 P. c. deserticola were incidentally captured by hand. In site $\mathrm{C}$ we recaptured one C. mormon that was initially captured in the same site. Coluber mormon were captured in all 4 sites, whereas $P$. $c$. deserticola were found in only 3 sites (A, B, and $\mathrm{C}$ ). 


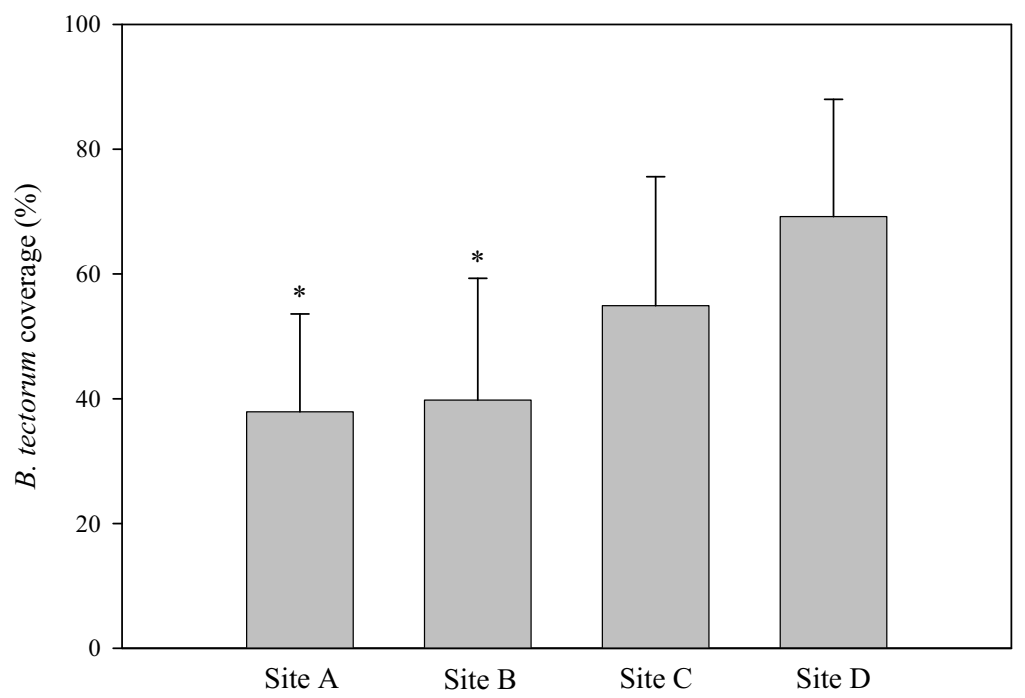

Fig. 3. Mean Bromus tectorum coverage (\%) determined by estimating abundance in each $1 \times 1$-m sample $(n=200$ samples per site). Bars represent one standard deviation. Nonsignificant correlations are noted with an asterisk (*). All other relationships were significant at $P<0.001$.

Relative abundance of C. mormon was negatively associated with percent coverage of $B$. tectorum $\left(F_{1,2}=22.06, P<0.05, R^{2}=0.92\right.$; Fig. 4). Likewise, P. c. deserticola relative abundance showed a significant negative relationship with $B$. tectorum coverage $\left(F_{1,2}=\right.$ 18.58, $P<0.05, R^{2}=0.90$; Fig. 4). There was no significant relationship between percent coverage of B. tectorum and C. mormon SVL $\left(F_{1,2}=0, P>0.05, R^{2}=0\right)$ or $P$. c. deserticola $\operatorname{SVL}\left(F_{1,2}=4.90, P>0.05, R^{2}=0.83\right)$. The sex ratio (males:females) for C. mormon did not significantly differ from parity $\left(11: 16 ; \chi^{2}=\right.$ 0.93 , df $=1, P>0.05)$. There were too few data to statistically compare the sex ratio for $P$. c. deserticola (3:4).

\section{Discussion}

We found that snake abundance was low in sites with high percentages of $B$. tectorum coverage on Antelope Island, a result that has important implications for the effects of B. tectorum invasions on native snake communities. In contrast, while working in southwestern Idaho, Cossel (2003) found that P. catenifer abundance was not impacted by B. tectorum and that C. constrictor was positively associated with it. Unlike our study, Cossel's study was not designed to explicitly measure relationships between snakes and B. tectorum but to monitor long-term changes in reptile communities. His rankings of vegetation abundance classified all the major cover types of vegetation on a 4-point scale and did not consider percentage differences among the highest (4, on his scale) B. tectorum rankings. Furthermore, since Cossel was replicating a previous study, he incorporated historical study sites that supported a diverse array of vegetation and geographical types. Thus, he was unable to directly examine correlations of B. tectorum with snake abundance in sites with similar habitat but differing B. tectorum abundance. Alternatively, his findings may illustrate the generalized habitat preferences of both snakes. It was apparent in our study that $C$. mormon and $P$. c. deserticola tolerate B. tectorum in lower coverages; however, it remains unknown if a tolerance threshold exists in this relationship. Most likely there are other factors contributing to low abundances of snakes in areas with high percentages of $B$. tectorum coverage.

Impeded locomotion is one factor that may negatively influence snake abundance in dense B. tectorum. Kelley et al. (1997) showed that snake locomotive performance was reduced as push-point density (in which nails inserted into boards represent vegetation stalks) surpassed intermediate levels. However, a similar study using field-established raceways for snakes in different densities of B. tectorum 


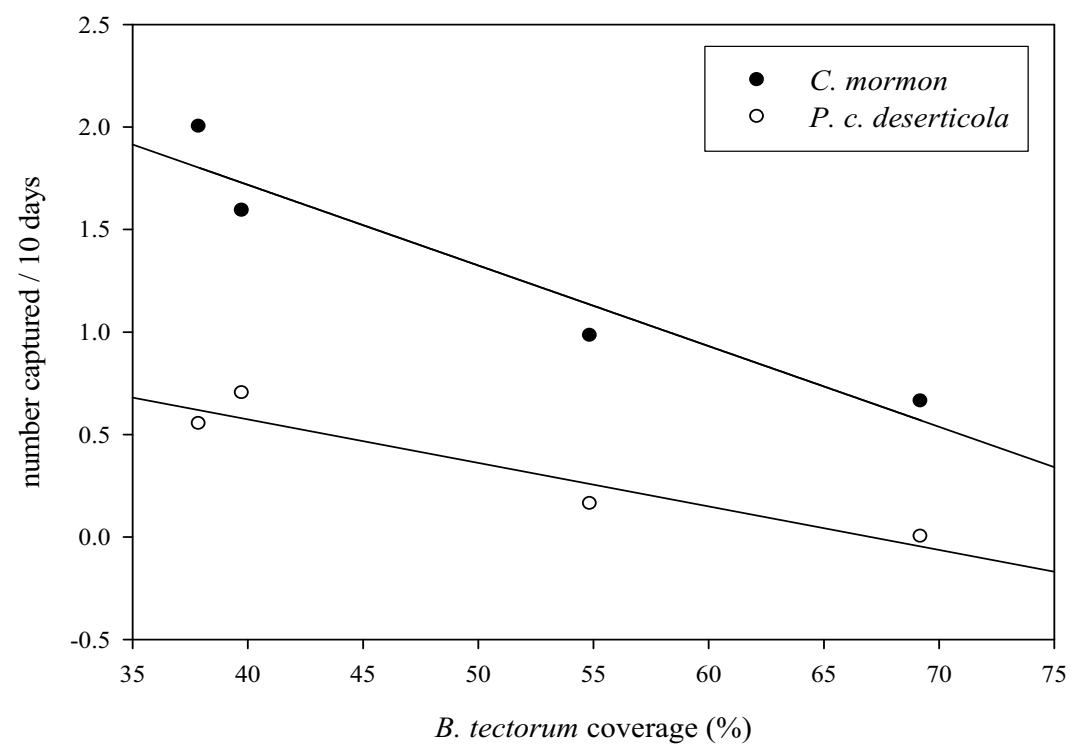

Fig. 4. Relative abundance (number of snakes captured per 10 days) of Coluber mormon $(Y=-0.040 X+3.321 ; n=$ $28)$ and Pituophis catenifer deserticola $(Y=-0.021 X+1.437 ; n=7)$ as a function of Bromus tectorum coverage $(\%)$.

could address how this grass may affect snake mobility. Dense vegetation could also impede burst speed and thus the ability of snakes to forage and escape predators such as badgers (Taxidea taxus) and coyotes (Canis latrans; Fitch 1949, 1963). Though B. tectorum could provide cover for snakes in some instances (e.g., avian predation), as snakes move through B. tectorum they also generate audible and visible cues disclosing their location (Mortensen 2004; personal observation).

Another factor that may contribute to few snakes in areas with high $B$. tectorum coverage is prey availability. Pituophis catenifer deserticola and C. mormon prey on a variety of organisms, such as small mammals, lizards, birds and their eggs, and insects (Fitch 1949, 1963, Klimstra 1959, Brown 1973, Parker and Brown 1980, Rosen 1991, Rodríguez-Robles 1998, Shewchuk and Austin 2001). Pituophis catenifer deserticola prefers small mammals (Parker and Brown 1980), whereas C. mormon prefers insects (Brown 1973). However, large C. mormon individuals have a broader diet that includes vertebrates (Rosen 1991, Shewchuk and Austin 2001).

Studies have shown that fewer small mammals are captured in B. tectorum sites than in sites with little or no B. tectorum, and factors such as lack of refuge and hindered movement have been mentioned as possibilities that could cause low small mammal abundances (Gano and Rickard 1982, Gitzen et al. 2001, Ostoja 2007). In southwestern Idaho, Yensen et al. (1992) performed transect surveys and found that the number of active Townsend's ground squirrel (Spermophilus townsendii) burrows were reduced in B. tectorum; they proposed that this may be because $B$. tectorum is a less-dependable food source for S. townsendii than other vegetation. Reduced rodent burrow availability may affect $C$. mormon and P. c. deserticola, which both utilize burrows for foraging, oviposition, and thermoregulation (Fitch 1949, Brown 1973, Brown and Parker 1976, Parker and Brown 1980, Rosen 1991, Rodríguez-Robles 2003).

Newbold (2005) found that desert horned lizard (Phrynosoma platyrhinos) velocity was negatively affected by $B$. tectorum and that $P$. platyrhinos was less abundant in areas with high B. tectorum cover. He attributed this effect to reduced foraging ability and to the wide body of $P$. platyrhinos, which causes it to move more slowly in $B$. tectorum than in other vegetation. Mortensen (2004) observed fewer sideblotched lizards (Uta stansburiana), western whiptails (Cnemidophorus tigris), and sagebrush lizards (Sceloporus graciosus) in areas with medium to high $B$. tectorum abundances 
on Antelope Island. He discovered that only $1 \%$ of the lizards encountered in areas with $B$. tectorum were actually found in B. tectorum; the remaining portion of lizards used open areas within B. tectorum.

Among birds, the shrub-dependent species have been most affected by B. tectorum. Decreasing populations have been observed among Sage Sparrows (Amphispiza belli), Brewer's Sparrows (Spizella breweri), and Sage Thrashers (Oreoscoptes montanus) because of habitat loss due to wildfire and, consequently, exotic grass invasions (Wiens and Rotenberry 1985, Knick and Rotenberry 1995, 2000).

Among snake prey species, grasshoppers are not significantly affected by B. tectorum. Craig et al. (1999) did not observe reduced grasshopper abundance or species richness as a function of increased B. tectorum coverage. However, they did not survey plots where $B$. tectorum was the dominant plant species. Fielding and Brusven (1993) found grasshoppers to be relatively abundant but less diverse on plots with high B. tectorum than on plots with low B. tectorum, and they also found that grasshoppers present in exotic annuals were primarily generalist pest species. An abundance of grasshoppers in disturbed sites with $B$. tectorum tentatively explains the presence of $C$. mormon in our sites with high $B$. tectorum coverage.

Less well understood are the indirect community effects of $B$. tectorum. Because C. mormon and $P$. c. deserticola serve as both predators of and prey for a number of other animals (Fitch 1949, 1963, Parker and Brown 1980), the lowered abundance of these snakes may alter the nature of predator-prey and competitive interactions in these communities. With the continued conversion of native shrubsteppe communities to grasslands by increased fire disturbance (Chambers et al. 2007), the effects of B. tectorum on community and ecosystem processes merit further investigation.

Future work on snakes could include studies that assess flee responses to predation. These would elucidate whether snakes use dense B. tectorum to escape predation and also what type of predation (e.g., aerial or cursorial) is most commonly evaded in B. tectorum. It would also be useful to investigate the effects that B. tectorum may have on snake locomotion and foraging success.

The degree to which populations of native fauna have been reduced or eliminated by $B$. tectorum has not been fully explored (Ostoja 2007). Our study is one of few that has attempted to assess the relationship between B. tectorum and shrubsteppe animals. Previous studies have shown reduced species abundance and diversity in areas with $B$. tectorum. Our study also demonstrates a trend of animal communities being adversely affected by $B$. tectorum.

\section{ACKNOWLEDGEMENTS}

This study would not have been possible without the efforts of N. Pietsch, E. Hall, K.N. Hall, C. Webb, K.E. Hall, M. Richardson, K. Richardson, B. Richardson, M. Warnes, S. Warnes, and J. Warnes. Special thanks go to G. Oliver (Utah Division of Wildlife Resources) and S. Newbold (Utah State University, Department of Biology) for sharing methodologies for studying reptiles and information about cheatgrass. We thank E. Hall, S. Newbold, N. Pietsch, E. Richardson, and C. Hoagstrom for comments on earlier drafts of this manuscript. Support for this research was provided by Antelope Island State Park and the Weber State University Office of Undergraduate Research. We express deep gratitude to S. Bates, J. Hatch, and G. Mortensen (Antelope Island State Park wildlife personnel) for field assistance, resource facilitation, island access, and the opportunity to conduct this research.

\section{Literature Cited}

AguiRre, L., AND D.A. Johnson. 1991. Influence of temperature and cheatgrass competition on seedling development of two bunch grasses. Journal of Range Management 44:347-354.

Brooks, M.L. 2000. Competition between alien annual grasses and native annual plants in the Mojave desert. American Midland Naturalist 144:92-108.

Brown, W.S. 1973. Ecology of the racer, Coluber constrictor mormon (Serpentes, Colubridae), in a cold temperate desert in northern Utah. Doctoral dissertation, University of Utah, Salt Lake City, UT.

Brown, W.S., AND W.S. PARKER. 1976. Movement ecology of Coluber constrictor near communal hibernacula. Copeia 1976:225-242.

CavitT, J.F. 2000. Fire and a tallgrass prairie reptile community: effects on relative abundance and seasonal activity. Journal of Herpetology. 34:12-20.

Chambers, J.C., B.A. Roundy, R.R. Blank, S.E. Meyer, And A. WhitTaker. 2007. What makes Great Basin sagebrush ecosystems invasible by Bromus tectorum? Ecological Monographs 77:117-145.

Collins, J.T., And T.W. TAGGarT. 2002. Standard common and current scientific names for north American amphibians, turtles, reptiles and crocodilians. 5th 
edition. Center for North American Herpetology, Lawrence, KS. 44 pp.

Cossel, J.O., JR. 2003. Changes in reptile populations in the Snake River Birds of Prey Area, Idaho between 1978-1979 and 1997-1998: The effects of weather, habitat and wildfire. Doctoral dissertation, Idaho State University, Pocatello, ID.

Craig, D.P., C.E. Bock, B.C. Bennet, and J.H. Bock. 1999. Habitat relationships among grasshoppers (Orthoptera: Acrididae) at the western limit of the Great Plains in Colorado. American Midland Naturalist 142:314-327.

D’Antonio, C.M., and P.M. Vitousek. 1992. Biological invasions by exotic grasses, the grass/fire cycle, and global change. Annual Review of Ecology and Systematics 23:63-87.

DaubenmiRe, R. 1959. A canopy cover method of vegetational analysis. Northwest Science 33:43-64.

Diller, L.V., and R.L. Wallace. 1996. Comparative ecology of two snake species (Crotalus viridis and Pituophis melanoleucus) in southwestern Idaho. Herpetologica 52:343-360.

Evans, R.D., R. Rimer, L. SPerry, and J. Belnap. 2001. Exotic plant invasion alters nitrogen dynamics in an arid grassland. Ecological Applications 11:1301-1310.

Fielding, D.J., AND M.A. BRUsven. 1993. Grasshopper (Orthoptera: Acrididae) community composition and ecological disturbance on southern Idaho rangeland. Environmental Entomology 22:71-81.

Fitch, H.S. 1949. Study of snake populations in central California. American Midland Naturalist 41:513-579.

. 1963. Natural history of the racer, Coluber constrictor. University of Kansas Publications, Museum of Natural History 15:351-468.

1987. Collecting and life-history techniques. Pages 143-164 in R.A. Seigel, J.T. Collins, and S.S. Novak, editors, Snakes: ecology and evolutionary biology, Macmillan, New York.

GaNO, K.A., AND W.H. RicKaRD. 1982. Small mammals of a bitterbrush-cheatgrass community. Northwest Science 56:1-7.

Gitzen, R.A., S.D. West, and B.E. Trim. 2001. Additional information on the distributions of small mammals at the Hanford site, Washington. Northwest Science 75:350-362.

Hirth, H.F., R.C. Pendleton, A.C. King, and T.R. DowNARD. 1969. Dispersal of snakes from a hibernaculum in northwestern Utah. Ecology 50:332-339.

Hulbert, L.C. 1955. Ecological studies of Bromus tectorum and other annual bromegrasses. Ecological Monographs 25:181-213.

Humphrey, L.D., AND E.W. Schupp. 2004. Competition as a barrier to establishment of a native perennial grass (Elymus elymoides) in alien grass (Bromus tectorum) communities. Journal of Arid Environments 58:405-422.

Kelley, K.C., S.J. Arnold, and J. Gladstone. 1997. The effects of substrate and vertebral number on locomotion in the garter snake Thamnophis elegans. Functional Ecology 11:189-198.

KLimstra, W.D. 1959. Foods of the racer, Coluber constrictor, in southern Illinois. Copeia 1959:210-214.

KNAPP, P.A. 1996. Cheatgrass (Bromus tectorum L) dominance in the Great Basin Desert: history, persistence, and influences to human activities. Global Environmental Change 6:37-52.
Knick, S.T., AND J.T. RotenberRy. 1995. Landscape characteristics of fragmented shrub-steppe habitats and breeding passerine birds. Conservation Biology 9:1059-1071.

2000. Ghosts of habitats past: contribution of landscape change to current habitats used by shrubland birds. Ecology 81:220-227.

MACK, R.N. 1981. Invasion of Bromus tectorum L. into western North America: an ecological chronicle. Agro-Ecosystems 7:145-165.

1989. Temperate grasslands vulnerable to plant invasions: characteristics and consequences. Pages 155-179 in J.A. Drake, H.A. Mooney, F. Di Castri, R.H. Groves, F.J. Kruger, M. Rejmanek, and M. Williamson, editors, Biological invasions: a global perspective. John Wiley \& Sons, Inc., New York.

MarshalL, W.H. 1940. A survey of the mammals of the islands in Great Salt Lake, Utah. Journal of Mammalogy 21:144-159.

Montensen, G. 2004. Antelope Island herptile study. Technical report submitted to Antelope Island wildlife personnel, Utah Division of Parks and Recreation, Salt Lake City, UT.

Newbold, T.A.S. 2005. Desert horned lizard (Phrynosoma platyrhinos) locomotor performance: the influence of cheatgrass (Bromus tectorum). Southwestern Naturalist 50:17-23.

NovaK, S.J., AND R.N. Mack. 2001. Tracing plant introduction and spread: genetic evidence from Bromus tectorum (cheatgrass). BioScience 51:114-122.

Ostoja, S.M. 2007. Context-dependent seed removal by granivorous rodents and seed harvesting ants. Doctoral dissertation, Utah State University, Logan, UT.

Parker, W.S., AND W.S. Brown. 1980. Comparative ecology of two colubrid snakes, Masticophis t. taeniatus and Pituophis melanoleucus deserticola, in northern Utah. Milwaukee Public Museum Publications in Biology and Geology 7:1-104.

Pimentel, D., L. Lach, R. Zuniga, and D. Morrison. 2000. Environmental and economic costs of nonindigenous species in the United States. BioScience 50:53-62.

Rodríguez-Robles, J.A. 1998. Alternative perspectives on the diet of gopher snakes (Pituophis catenifer, Colubridae): literature records versus stomach contents of wild and museum specimens. Copeia 1998:463-466.

2003. Home ranges of gopher snakes (Pituophis catenifer, Colubridae) in central California. Copeia 2003:391-396.

Rosen, P.C. 1991. Comparative ecology and life history of the racer (Coluber constrictor) in Michigan. Copeia 1991:897-909.

Schaefer, W.H. 1934. Diagnosis of sex in snakes. Copeia 1934:181.

Shewchuk, C.H., AND J.D. Austin. 2001. Food habits of the racer (Coluber constrictor mormon) in the northern part of its range. Herpetological Journal 11:151-155.

SPELlerberG, I.F. 1977. Marking live snakes for identification of individuals in population studies. Journal of Applied Ecology 14:137-138.

Stewart, G., AND A.C. Hull. 1949. Cheatgrass (Bromus tectorum L.) - an ecological intruder in southern Idaho. Ecology 30:58-74.

Wiens, J.A., AND J.T. Rotenberry. 1985. Response of breeding passerine birds to rangeland alteration in 
a North American shrub-steppe locality. Journal of Applied Ecology 22:655-668.

Yensen, E., D.L. Quinney, K. Johnson, K. Timmerman, And K. Steenhof. 1992. Fire, vegetation changes, and population fluctuations of Townsend's ground squirrels. American Midland Naturalist 128:299-312.
Young, J.A., And R.A. Evans. 1978. Population dynamics after wildfires in sagebrush grasslands. Journal of Range Management 31:283-289.

Received 15 January 2008 Accepted 15 September 2008 